\title{
Chrystyna Nikołajczuk
}

ORCID: 0000-0003-1703-7830

Lwowski Uniwersytet Narodowy im. Iwana Franki

https://doi.org/10.19195/1642-5782.18(28).6

\section{Słuchowisko radiowe na zajęciach języka polskiego jako obcego: pomysł lekcji oraz opinie studentów lwowskiej polonistyki}

\section{Słuchowisko radiowe jako przedmiot badań medioznawstwa i dydaktyki}

Życie codzienne człowieka jest nierozłącznie związane ze światem najrozmaitszych dźwięków. Foniczna forma każdego języka zajmuje szczególne miejsce w akustycznej mozaice codzienności. Akt komunikacji międzyludzkiej uznaje się za udany, gdy perlokucja w mniejszym lub większym stopniu odpowiada illokucji. Niezbędnym warunkiem jest między innymi nadawca posługujący się kodami zrozumiałymi dla jego rozmówcy oraz odbiorca nie tylko słyszący, lecz przede wszystkim słuchający, próbujący właściwie zinterpretować nadawany komunikat. Proces porozumienia się ludzi staje się jeszcze trudniejszy, gdy języki ojczyste rozmówców są różne. W takiej sytuacji mówiący językiem obcym stoi przed nie lada wyzwaniem: powinien on bowiem nie tylko odczytać warstwę werbalną tego języka poprzez rozszyfrowanie znaczenia osobnych wyrazów, lecz także wniknąć w sposób myślenia, zachowania się rodzimego użytkownika. $\mathrm{Z}$ pewnością nie jest to łatwe zadanie, lecz nie należy do niewykonalnych. W procesie glottodydaktycznym ważną rolę odgrywa kontakt z żywym językiem. Ucząc się języka polskiego poza obszarem Polski, obcokrajowiec powinien otaczać się jak największą liczbą autentycznych tekstów i wypowiedzi (nagrań). Ich wybór w nauce języka obcego należy potraktować bardzo poważnie. Muszą one służyć 
za wzorzec żywego, ale też poprawnego języka polskiego. Nagrania wypowiedzi mają dodatkową zaletę dla uczącego się polszczyzny, rozwijają bowiem jego słuch fonematyczny, z czym także jest związana poprawna artykulacja polskich głosek, zwłaszcza zbitek głoskowych. Poza tym właśnie z wypowiedziami obcokrajowiec najczęściej ma do czynienia w polskojęzycznej komunikacji, jak podczas nawiązywania różnego typu kontaktów z Polakami (dialogi dotyczące sfery obsługi, na przykład w restauracji i środkach lokomocji publicznej, sklepach itp.) oraz wygłaszania dłuższych wypowiedzi w sytuacjach oficjalnych (na przykład w pracy) i nieoficjalnych (spotkania towarzyskie).

W niniejszym artykule skupię się na jednym z takich utworów audialnych, a mianowicie na słuchowisku radiowym, które może się przydać, a nawet świetnie się sprawdzić na zajęciach z języka polskiego jako obcego (dalej: JPJO). Zaprezentuję swoje pomysły na lekcję opartą na materiale słuchowiska radiowego pod tytułem Józio oraz przedstawię opinie moich studentek na temat wykorzystania takich utworów w nauce JPJO.

Sztuka audialna przyciąga uwagę wielu badaczy, zwykle medioznawców. Należy tu wspomnieć chociażby monografie Elżbiety Pleszkun-Olejniczakowej, Joanny Bachury i Aleksandry Pawlik Dwa Teatry. Studia z zakresu teorii $i$ interpretacji sztuki stuchowiskowej (2011); Joanny Bachury Odsłony wyobraźni. Wspótczesne stuchowisko radiowe (2012); Aleksandry Pawlik Teatr radiowy i jego gatunki (2014); Sławy Bardijewskiej Nagie słowo: rzecz o stuchowisku (2001) itp. O korzyściach płynących ze słuchowiska radiowego w glottodydaktyce napisała Anna Trębska-Kerntopf w artykule Co stychać w stuchowisku, czyli o technikach pracy z teatrem wyobraźni na zajęciach języka polskiego jako obcego (2008), gdzie w postaci tabelki autorka podaje 27 interesujących technik i strategii wykorzystania słuchowiska radiowego na zajęciach JPJO. Wart uwagi jest również artykuł (choć nie porusza wątków glottodydaktycznych) Magdaleny Osowickiej-Kondratowicz „Bajki samograjki”, czyli o stuchowiskach i ksiażkach do stuchania w rozwoju mowy dziecka (2018). Temat ten jednak nie cieszy się szczególnym zainteresowaniem wśród glottodydaktyków: poza wymienionymi pozycjami nie udało mi się znaleźć więcej artykułów o wykorzystaniu słuchowisk radiowych na zajęciach JPJO.

\section{Słuchowisko czas zacząć...}

Wbrew temu, że słuchowiska radiowe od dawna są nadawane w Polsce, ich rola w ujęciu glottodydaktycznym pozostaje wciąż niedoceniona. Obcokrajowcy uczący się polszczyzny często po prostu nie wiedzą o istnieniu tak bogatego źródła. Słuchowisko stosunkowo niedawno stało się przedmiotem moich zainteresowań. Pewnego styczniowego dnia 2020 roku w serwisie internetowym YouTube zaproponowano mi do posłuchania Gościa wigilijnego z 1997 roku autorstwa 
Adama Baumana (https://www.youtube.com/watch?v=YIRRTDej-tI). Ten utwór zainspirował mnie do poznania kolejnych słuchowisk i poszukiwania sposobów na wprowadzenie ich na zajęciach z JPJO. Należy podkreślić, że zadania dotyczące tego rodzaju sztuki radiowej przypadły uczniom do gustu. Nawet jeżeli nie mieli oni wystarczająco dużo czasu na wykonanie przygotowanych przeze mnie ćwiczeń, zawsze słuchali samego utworu, chętnie omawiali treść, fabułę, różne wątki. Widzę żywe zainteresowanie utworami radiowymi. Poniżej podaję przykład lekcji skonstruowanej na podstawie słuchowiska Józio z 2005 roku autorstwa Marka Ławrynowicza (https://www.youtube.com/watch?v=_IME_h9nL$\mathrm{HA} \& \mathrm{t}=14 \mathrm{~s}$ ). Jest to niezwykle wzruszająca opowieść o umierającym staruszku, wolontariuszu i pewnej marionetce o imieniu Józio, która odegrała bardzo ważną rolę w życiu, jak się później okazało, obu bohaterów.

Lekcja składa się z ćwiczeń doskonalących różne sprawności językowe. Zaczyna się od ogólnych pytań dotyczących fabuły słuchowiska (Czy pamiętasz?). Rubryka Poprawmy to jest zadaniem na rozumienie ze słuchu (choć w zasadzie samo słuchowisko jest takim ćwiczeniem, bez zrozumienia treści utworu nie da się bowiem wykorzystać go na zajęciach). Wiele ćwiczeń jest poświęconych słownictwu (Co się przyciaga?), frazeologii (Z pamiętnika mojej zielonookiej lalki), gramatyce (Nazwij mnie po imieniu). Proponuję również rozwinąć dodatkowe wątki (wolontariat, teatr lalek, rola zabawek i lalek w życiu dziecka) pojawiające się w słuchowisku (Co o tym myślisz?). Ponadto staram się uwypuklić trudne dla Ukraińca uczącego się polszczyzny zagadnienia (wymowa spółgłoski [1] (wiersz Lalki i koleżanki; dodatkowe uwagi Pamiętajmy). Zachęcam do wejścia na strony internetowe, na których można zobaczyć polskie plakaty teatralne oraz pewien film animacyjny, związany z plakatami.

\section{SEUCHOWISKO RADIOWE JÓZIO}

Autor: Marek Ławrynowicz

Reżyseria: Janusz Kukuła

Obsada: Krzysztof Gosztyła, Grzegorz Damięcki

Emisja: 30.11.2005

Legalne źródło słuchowiska: https://www.youtube.com/watch?v=_IME_h9nLHA (dostęp bezpłatny)

„Dobranoc Marku lampę zgaś"

(cytat z wiersza Z. Herberta Do Marka Aurelego, do którego nawiązuje bohater słuchowiska, pan Kazimierz) 


\section{Czy pamiętasz...}

- Ilu osobom pomógł Andrzej?

- O jakim tunelu wspomina pan Kazimierz? Kto będzie czekał na pana Kazimierza na końcu korytarza?

$\checkmark$ Dlaczego pan Kazimierz nazywa wolontariusza dziwakiem?

$\checkmark$ Kim jest pan Kazimierz?

- Kogo marzył zagrać pan Kazimierz? Dlaczego ten bohater zwariował?

- W jaki sposób pan Kazimierz chciałby skorzystać z pomocy wolontariusza?

- Co sprawiło, że pana Kazimierza wybrano do animowania?

- W jakim celu stworzono Józia?

$\checkmark$ Dlaczego pan Kazimierz wrócił do teatru?

• Czym się interesuje Józio? Czym się zajmował po śniadaniu pan Kazimierz?

- Co robił pan Kazimierz, gdy Józio wpadał w depresję?

• Kogo ze „starych naiwniaków” nie czytał Andrzej?

Co z tych przedmiotów, rzeczy, zwierząt pojawiło się w shuchowisku? Z jakimi wydarzeniami sq one zwiąane?

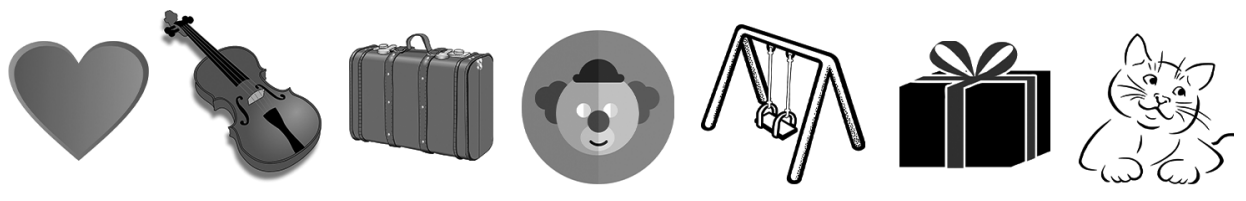

\section{Poprawmy to}

W poniższych dialogach znalazły się niewłaściwe stowa. Znajdź te wyrazy i zamień je na poprawne. Następnie uporządkuj kolejność występowania dialogów w stuchowisku.

Przyktad:

a) - Zwróciłeś uwagę, Andrzeju, w jaki sposób on mówi?

- Tak trochę skwapliwie.

— No właśnie. To się nazywa „głos charakterystyczny”.

Niewłaściwe stowo: skwapliwie. Poprawne stowo: skrzekliwie. 


\begin{tabular}{|c|c|}
\hline $\begin{array}{l}\text { b) - Co słychać, Józiu? } \\
\text { - Piękna wygoda. }\end{array}$ & $\begin{array}{l}\text { g) - Mam na imię Andrzej. } \\
\text { - Idiotycznie, ale nie Szkoci. }\end{array}$ \\
\hline $\begin{array}{l}\text { c) — To pan jest aktorem? } \\
\text { — Aktor... To za duże słowo. Byłem leka- } \\
\text { rzem. }\end{array}$ & $\begin{array}{l}\text { h) - A to, że przychodzę, nie pomaga panu? } \\
\text { — Ani trochę, jeżeli mam być szczery. Ale } \\
\text { wstań, wstań, proszę. }\end{array}$ \\
\hline $\begin{array}{l}\text { d) - Oho, jaka dziwna lalka. } \\
\text { — Nie lalka, tylko kokietka. }\end{array}$ & $\begin{array}{l}\text { i) - Ja nic nie wiem o zarabianiu. } \\
\text { — Uśmiejesz się, ale ja też nie. }\end{array}$ \\
\hline $\begin{array}{l}\text { e) - Chyba nie chcesz powiedzieć, młody } \\
\text { człowieku, że uśmiechałem się do kobiecości? } \\
\text { — Eee, wcale o tym nie myślałem. }\end{array}$ & $\begin{array}{l}\text { j) - Czy jesteś pewien, że tego naprawdę } \\
\text { chcesz? } \\
\text { - Oczywiście, to przecież nic takiego. }\end{array}$ \\
\hline $\begin{array}{l}\text { f) - I trzeba przyznać, że od razu zrobiło się } \\
\text { ciekawie. } \\
\text { - Aaa, czyli sukces. } \\
\text { - Niestety, publiczny. }\end{array}$ & $\begin{array}{l}\text { k) — I bardzo się z ciebie śmiali, łajdaku? } \\
\text { — Nikt się nie śmiał. Wszyscy chcieli mnie } \\
\text { huśtać. }\end{array}$ \\
\hline
\end{tabular}

\begin{tabular}{|l|l|l|l|l|l|l|l|l|l|l|}
\hline $\mathbf{1}$ & $\mathbf{2}$ & $\mathbf{3}$ & $\mathbf{4}$ & $\mathbf{5}$ & $\mathbf{6}$ & $\mathbf{7}$ & $\mathbf{8}$ & $\mathbf{9}$ & $\mathbf{1 0}$ & $\mathbf{1 1}$ \\
\hline & & & & & & & & $\mathrm{a}$ & & \\
\hline
\end{tabular}

\section{Na czym polega dowcip językowy w takim fragmencie:}

- A wiesz, kto to Gogol?

- Przerabialiśmy w szkole Rewizora.

— Na co przerabialiście?

Co się przyciaga?

Uzupetnij poniższe wyrażenia $i$ zdania. Czy rozumiesz ich znaczenia? Co bohaterowie chcieli wyrazić za pomoca tych stów?

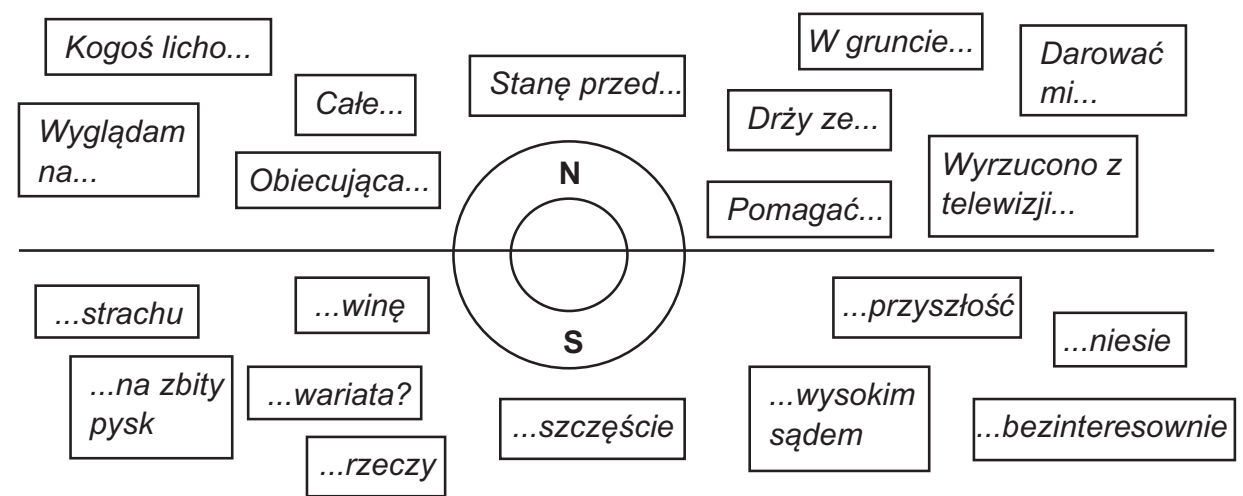


Nazwij mnie po imieniu...

$W$ tytule stuchowiska radiowego wykorzystano imię Józio. Czy wiesz, jaka jest petna forma tego imienia? Niziej podane sa zdrobnienia innych polskich imion. Spróbuj samodzielnie podać ich petna formę. Które polskie imię podoba Ci się najbardziej? Czy chciałabyś/chciałbyś zmienić swoje imię? Dlaczego?

\begin{tabular}{|c|c|c|c|}
\hline \multicolumn{2}{|r|}{ IMIONA MESKIE $\delta^{\lambda}$} & \multicolumn{2}{|r|}{ IMIONA ŻEŃSKIE $q$} \\
\hline $\begin{array}{l}\text { pełna } \\
\text { forma }\end{array}$ & zdrobnienie & $\begin{array}{l}\text { pełna } \\
\text { forma }\end{array}$ & zdrobnienie \\
\hline & Janek, Jaś, Jasiek, Jasio, Jasiu & & $\begin{array}{l}\text { Marysia, Marylka, Marynia, } \\
\text { Marysieńka, Maryśka, Maryś, } \\
\text { Maryjka }\end{array}$ \\
\hline & $\begin{array}{l}\text { Staś, Staszek, Stasiek, Stasiu, } \\
\text { Stasio, Stasiulek, Stach }\end{array}$ & & $\begin{array}{l}\text { Krysia, Krysieńka, Kryśka, } \\
\text { Krystynka, Krysieczka }\end{array}$ \\
\hline & $\begin{array}{l}\text { Andrzejek, Andrzejuś, Jędrek, } \\
\text { Jędruś }\end{array}$ & & Ania, Aneczka, Anulka \\
\hline & Józek, Józuś, Józio & & Basia, Baśka, Basieńka, Bacha \\
\hline & Tadek, Tadzio & & Terenia, Tereska, Terka \\
\hline & Jurek, Jureczek, Jerzyk & & Ela, Elżunia, Elka \\
\hline & Zbyszek, Zbynio, Zbych & & Jasia, Janka, Janeczka \\
\hline & $\begin{array}{l}\text { Krzysiek, Krzyś, Krzychu, Krzysio, } \\
\text { Krzych }\end{array}$ & & $\begin{array}{l}\text { Zosia, Zosieńka, Zosiek, Zośka, } \\
\text { Zofka }\end{array}$ \\
\hline & Heniek, Henio, Henryczek & & Jadzia, Jagoda, Jadziunia \\
\hline & Rysiek, Rysiu, Rysio, Ryś & & Danusia, Danka \\
\hline
\end{tabular}

Na podstawie: https://imiona.nazwiska-polskie.pl/.

\section{W poniższym tekśsie prosze użyć wyrazu imię $w$ odpowiednim przypadku.}

Mam na 1 Józio (co właściwie jest zdrobnieniem 2 Józef). Bez dwóch zdań jest to najpiękniejsze ze wszystkich 3 mniej jednak istnieją również inne ładne 4 .5 na całej planecie, niekażdego człowieka jest niezwykle ważne dla niego. Dlatego staram się zwracać do ludzi po 6 Szczególnie lubię rodzime 7 _. Czasami biorę kalendarz z 8 i przyglądam się tym 9 _. Niekiedy myślę o rzadkich 10 one odchodzą w zapomnienie? Przecież dzięki oryginalnemu 11 . Dlaczego wyróżnić się z tłumu, podkreślić swoją wyjątkowość. Takie myśli chodza mi po głowie. A wieczorami po cichu marzę, żeby moim 12 w najlepszym konkursie lalkarskim. nazwano nagrodę 


\section{Co o tym myślisz?}

$>$ Czy jest potrzebny wolontariat? Co sądzisz o wprowadzeniu godzin wolontariatu na uczelniach wyższych, w szkołach?

$>$ Dlaczego ludzie decydują się na wolontariat?

$>$ Czy znasz jakieś organizacje charytatywne w Polsce i w Twoim kraju? Czym one się zajmują?

Czy potrafisz pięknie wymówić głoskę [l]? Spróbuj!

\section{Lalki i koleżanki}

Ala, Ola, Ula, Ela mają lalki. Lalka Ali to Lola.

Lalka Oli to Kola.

Lalka Uli to Milka.

Lalka Eli to Lilka.

Pojechały raz na molo, popijając lody colą.

Tam też plotły różne plotki: Ala, Ola, Ula, Ela. Lato było to upalne, no więc wielka kąpiel w wannie była teraz w dalszych planach:

Ali, Loli, Oli, Koli, Ulki, Milki, Eli, Lilki.

A. Walencik-Topitko

(http://www.happytoys.pl/wiersze-logopedyczne/lalki-i-kolezanki) $\checkmark \quad$ Czy zgadzasz się ze zdaniem pana Kazimierza: „A kto z nas jest tak naprawdę dorosły?".

$\checkmark$ Co sądzisz o teatrze lalek? Czy oglądanie przedstawień teatralnych jest popularne w Twoim kraju?

$\checkmark$ Co znaczy „teatrzyk domowy”? Czy kiedykolwiek byłeś aktorem w takim teatrzyku?

$\checkmark \quad$ Dlaczego w życiu dziecka tak ważne są zabawki i lalki?

\section{Pamiętajmy:}

Im..., tym... - Чим..., тим...

Im bardziej byt okropny, tym bardziej dzieci go uwielbialy.

przedstawienie, spektakl - вистава (wystawa - виставка, експозичія) 
Przeczytaj wspomnienia pewnej lalki o swojej właścicielce. Wyttuszczone zostały frazeologizmy. Zastanów się, co moga one znaczyć.

A co by powiedzialy Twoje lalki/zabawki, gdyby umialy mówić? Napisz krótka historię, wykorzystując dowolnefrazeologizmy (można wykorzystaćfrazeologizmy, które pojawity się w stuchowisku).

\section{Z pamiętnika mojej zielonookiej lalki.}

Nieważne, ile lat będziesz miała na karku, jak krótkie będą Twoje włosy i jak często będziesz zmieniała ich kolor. Jestem na wyciągnięcie ręki. Jestem na każde zawolanie. Któż to jeszcze może powiedzieć o Tobie tyle, ile ja? Znam Cię na wylot. $\mathrm{Na}$ święta zajadałam się z Tobą makowymi bułeczkami. Palce lizać! Twoja mama rzeczywiście ma złote ręce! Przypominam sobie, że ciągle chodzilaś $\mathbf{z}$ glową $\mathbf{w}$ chmurach. I choć wypierasz się tego, nadal taka jesteś... A pamiętasz granatową sukienkę w białe stokrotki? Ona leżala na Tobie jak ulal. Nie mogłam oczu od Ciebie oderwać... Połykałam łzy, kiedy spadłaś z roweru i nabilaś sobie guza. Biegłam z Tobą co tchu, kiedy niosłaś tacie niezapominajki, zebrane na wiejskiej łące. Podsłuchiwałam, jak szeptem (bo ściany mają uszy!) opowiadałaś siostrzyczce, gdzie zakopałaś swój skarb — suszony listek pod małym szkiełkiem. To ja zmierzylam spojrzeniem chłopaka, który przyniósł Ci naręcze kwiatów na Twoje urodziny. A potem Ty posłałaś mu ręką całusa. To ja...

Mogłabym snuć bez końca te opowieści o również zielonookiej dziewczynce.

Żyjesz pelną piersią i masz pelne ręce roboty. Zostanę przy Tobie.

Będę czekała w nieskończoność, aż pewnego dnia dotknę rączki Twojej córki.

$$
* * *
$$

\section{...coś dla mocno zaangażowanych $w$ temat;)}

Wejdź na stronę wybranego przez Ciebie polskiego teatru i na podstawie zdjęć do wybranego przedstawienia ułóż własną magiczną historię.

* Podaj swoją receptę na udany spektakl.

* Jaką rolę w życiu teatralnym odgrywa plakat? Za dodatkowe źródło inspiracji może posłużyć krótka animacja Juliana Antonisza Ostry film zaangażowany (https://www.youtube.com/watch?v=9uxlXIlihWA).

* Opisz swój ulubiony plakat teatralny. Plakaty możesz zobaczyć na stronach:

https://artsandculture.google.com/exhibit/WwIi_WjnCr0FLw?hl=pl

https://www.galeriagrafikiiplakatu.pl/pl/plakaty/217/Jerzy-Srokowski/9681/ Szkoda-wasow-1964-r/?\&imgpos $=0$

Stwórz plakat ulubionej sztuki. 


\section{Słuchowisko radiowe: sztuka dla sztuki czy sztuka dla glottodydaktyki?}

Taka lekcja stała się wzorcem dla moich studentek, które z kolei miały wybrać dowolne polskie słuchowisko i przygotować swoje ćwiczenia, uwzględniając jak najwięcej zagadnień (nauczanie wymowy i intonacji, słownictwa, gramatyki) oraz sprawności językowe (słuchanie, czytanie, pisanie, mówienie). Ważnym warunkiem było stworzenie urozmaiconej lekcji na poziomie B1-B2. Studentki wybierały słuchowiska różnorodne tematycznie, o łącznym czasie 9 godzin nagrań, których miałam przyjemność wysłuchać. Sporadycznie słuchowiska się powtarzały, ale było to tym bardziej interesujące - przygotowane na podstawie tego samego materiału lekcje wyraźnie się różniły, zostały uwypuklone inne aspekty tego samego utworu, dopasowano inne tematy gramatyczne. Przykładowo słuchowisko radiowe Czarna pani z 1971 roku autorstwa Kazimierza Orłosia (https://www.youtube.com/watch? $\mathrm{v}=6 \mathrm{aOAMAX} 95 \mathrm{IE} \& \mathrm{t}=75 \mathrm{~s}$ ) wykorzystały w swoich lekcjach dwie studentki (z różnych roczników). Jedna wprowadziła ćwiczenia na tryb rozkazujący, ponieważ te formy często występowały w samym słuchowisku, a druga - odmianę liczebników i wyrazów złoty/grosz (jest to nawiązanie do treści słuchowiska: turyści chcieli zostać w domu tylko na jedną noc i musieli zapłacić za nocleg).

Czasami wybór padał na słuchowiska z połowy XX wieku. Chodzi na przykład o słuchowisko Czy pan istnieje, mr Johns? z 1955 roku autorstwa Stanisława Lema, w reżyserii Michała Meliny (https://www.youtube.com/watch?v=2k$\mathrm{SNx}-J z 4 N A \& t=463 \mathrm{~s})$. Wcale nie podważam wartości artystycznej tego utworu, należy się jednak zastanowić nad wykorzystaniem tego słuchowiska w nauce JPJO. Występuje tu stary wzorzec wymowy polskiej (na przykład wymowa ge jako gie: marki geniusz (7.34 min nagrania) czy też przestarzałe formy gramatyczne, na przykład bogaczów (19.43, teraz tylko bogaczy). Taki materiał można wprowadzić na zajęciach z polonistami $\mathrm{w}$ celu zilustrowania pewnych zmian językowych. W przypadku studentów innych kierunków sugerowałabym raczej słuchowiska wykorzystujące środki językowe współczesnej polszczyzny (chyba że chodzi o wyższe poziomy znajomości języka polskiego, kiedy to uczący się ma już dość dobrze rozwiniętą świadomość językową).

Niestety w lekcjach przygotowanych przez studentki stosunkowo rzadko pojawiały się wątki dotyczące polskiej kultury, a takie można znaleźć w prawie każdym słuchowisku. Powodów może być kilka: albo studentki nie uznały aluzji dotyczących kultury polskiej za ważne elementy, które warto wprowadzić do lekcji, albo po prostu same ich nie zauważyły. Mianowicie, w żaden sposób w konspekcie lekcji nie wspomina się tytułu książki Hanny Krall Zdążyć przed Panem Bogiem, wymienianego przez jednego z bohaterów słuchowiska Wirus autorstwa Bogdana Loebla (1.16; emisja: 2006; https://www.youtube.com/watch?v=s7kI48UxcKU). 
Co gorsza, inna studentka (nawiasem mówiąc bardzo zdolna) w swojej lekcji (na podstawie słuchowiska Spadkobiercy autorstwa Kazimierza Orłosia, emisja: 2014; https://www.youtube.com/watch?v=YSy_EwXYNcM) pomyliła imię znanego malarza pochodzenia łemkowskiego, Nikifora Krynickiego, upamiętnionego między innymi w filmie fabularnym Krzysztofa Krauzego pod tytułem Mój Nikifor (pomnik tego artysty stoi we Lwowie). Należy podkreślić, że nie wszystkie elementy kulturowe występujące w słuchowiskach są czytelne również dla mnie - obcokrajowca nieustannie uczącego się polszczyzny, polskiej historii i kultury. Mianowicie, w słuchowisku Złodziej głosów autorstwa Adama Baumana (emisja: 2008; https://www.youtube.com/watch?v=vtYQ7mmkRNg) główny bohater mówi, że zlecony materiał odda: „Najwcześniej w środę. A puścicie w czwartek po Dzienniku, zamiast Kobry”. Wyraz „kobra” kojarzył mi się tylko z jednym znaczeniem - 'duży, jadowity wąż', które wcale nie pasowało do ogólnego tła wypowiedzi. W słuchowisku jednak chodziło o Teatr Sensacji „Kobra”telewizyjne przedstawienie kryminalne nadawane w drugiej połowie XX wieku. Ten szczegół nie wpływa na zrozumienie ogólnej treści słuchowiska. Zdaję sobie sprawę również z tego, że młodzi Polacy też mogą nie odczytać wszystkich aluzji do pewnych programów, wydarzeń, postaci, pojawiających się w słuchowisku itp. Każdy taki element jest jednak, moim zdaniem, jednym z istotnych puzzli tworzących historyczno-kulturalną mozaikę kraju. Uważam, że należy uczulać naszych uczniów na różnego typu wątki kulturalne, pojawiające się w różnych tekstach, w tym także w słuchowisku radiowym. Niestety obecnie na lwowskiej polonistyce nie ma osobnego przedmiotu poświęconego polskiej kulturze, są odczuwalne niedostatki wiedzy w tym zakresie. Należy zatem na różne sposoby nadrabiać zaległości, zwłaszcza gdy ma się do dyspozycji tak wspaniałe utwory audialne.

Oprócz przygotowania ćwiczeń na materiale słuchowiska studentki miały wypełnić ankiety, na podstawie których mogłam wywnioskować, czy tego typu zadanie przypadło im do gustu i czy zechcą wprowadzać je na swoich zajęciach. Nawiasem mówiąc, są to studentki IV roku studiów licencjackich (otrzymałam 18 ankiet $^{1}$ ) oraz I roku studiów magisterskich (6 ankiet). Jest to wyjątkowo dobra grupa respondentów: większość ankietowanych pełni bowiem dwie funkcje zawodowe - osoby te są studentkami i jednocześnie nauczycielkami (zwykle w szkole ogólnokształcącej albo w szkołach językowych). A zatem była to dobra okazja do przeanalizowania, jaki jest stosunek do takich zadań zarówno uczących się języka, jak i lektorów. Ankieta zawierała pięć pytań, które zostaną po kolei omówione.

I. Dla mnie sluchowisko radiowe to: 1) ...; 2) ...; 3) ... (proszę podać minimum trzy słowa kojarzace się Pani ze stuchowiskiem radiowym).

${ }^{1} \mathrm{~W}$ nawiasach podaję liczbę ankiet, a nie osób w grupie, ponieważ nie wszystkie studentki wysłały wypełnione ankiety. 
Odpowiadając na pytanie, studentki podały nie tylko swoje skojarzenia, lecz także pewne zalety wykorzystania słuchowiska radiowego na zajęciach JPJO. Wszystkie zgromadzone odpowiedzi da się podzielić na pięć grup:

1.1. szeroko rozumiana sfera edukacji - 22 odpowiedzi: praktyka (3); (nowe) doświadczenie (2); nowe metody nauczania (2); nowe; nauczenie się języka polskiego w sposób nietypowy, ciekawy; coś niezwykłego; kreatywna metoda nauczania JPJO; edukacyjnie; informacja; stownictwo; być kulturalnym itp.;

1.2. świat dzieł sztuki, twórczość — 19: rozwój wyobraźni (4); (ciekawa) historia (5); teatr (wyobraźni) (2); sztuka (2); książki; wystawa artystyczna; twórczość; artystyczność itp.;

1.3. warstwa foniczna - 13: dźwięk (4); głosy ludzi (3); rozmowy; muzyka; cisza; tekst audialny; stuchanie itp.;

1.4. procesy poznawcze; rozwijanie własnych umiejętności - 8: uwaga (3); skupienie (2); koncentracja; rozumienie; bodziec do myślenia;

1.5. inne, w tym sfera uczuć, przeżyć człowieka - 8: strach nie zrozumieć czegoś; emocje; podróż; owocnie spędzony czas; mało czasu.

II. Drugie pytanie dotyczyło bezpośrednio zalet wykorzystania słuchowiska radiowego na zajęciach JPJO. Zgodnie z odpowiedziami respondentek, słuchowisko:

2.1. rozwija sprawność rozumienia ze stuchu (13);

2.2. jest wzorcem poprawnej wymowy (12);

2.3. jest podstawa do przygotowania urozmaiconych zadań (8);

2.4. polepsza pamięć stuchowa (6);

2.5. jest skuteczna zachęta do mówienia (6);

2.6. jest interesujacym sposobem na naukę języka obcego (6);

2.7. rozwija zdolność koncentracji uwagi (5);

2.8. wzbogaca stownictwo (4);

2.9. umożliwia kontakt z żywym językiem, językiem mówionym (4);

2.10. dostarcza nowa informacje (3);

2.11. pobudza wyobraźnię (3);

2.12. rozwija poczucie estetyki, wrażliwość artystyczna, a co za tym idzie pomaga nam lepiej wyrazić własne emocje (3);

2.13. da się stuchać podczas wykonywania innych czynności (2);

2.14. można wykorzystać jako materiat dydaktyczny w wieloosobowej grupie (1).

III. Odpowiadając na trzecie pytanie, studentki dzieliły się swoimi refleksjami na temat tego, co należy uwzględnić podczas wykorzystania słuchowiska radiowego na zajęciach JPJO. Respondentki uważają, że:

3.1. stuchowisko powinno być interesujace (8);

3.2. stuchowisko powinno odpowiadać wiekowi i poziomowi uczniów (8);

3.3. stuchowisko powinno być krótkie (7); 
3.4. stuchowisko powinno być dobrej jakości (chodzi o jakość nagrania) (4);

3.5. sam proces stuchania tego utworu powinien odbywać się $w$ domu, nie na zajęciach (3);

3.6. nie jest to zadanie dla każdego, ponieważ nie wszyscy sa stuchowcami (3);

3.7. lekcje tego typu powinny być urozmaicone tematycznie: za każdym razem należy wybrać inny rodzaj historii (1);

3.8. lekcja oparta na stuchowisku nie powinna zawierać dużo zadań (1).

Pięć studentek nie podało żadnych uwag, a jedna wyraziła swój żal, że wcześniej nie miała do czynienia z takimi tekstami: Tak naprawde nigdy nie miałam sprawy ze stuchowiskiem radiowym, i to okropnie. Dla mnie to byto interesujace doświadczenie i myślę, że będę korzystać z tych nagrań w czasie wolnym. Moim zdaniem, to świetne ćwiczenie dla uczniów. Nie mam nic przeciwko temu ${ }^{2}$.

Celem kolejnych dwóch pytań było sprawdzenie, czy studentki chciałyby pracować ze słuchowiskiem na zajęciach JPJO.

IV. Czy Pani jako nauczycielka zamierza wykorzystywać słuchowisko radiowe na zajęciach $\mathrm{JPJO}^{3}$ ?

\begin{tabular}{|l|c|c|c|c|}
\hline \multicolumn{1}{|c|}{ raczej tak } & tak & nie & raczej nie & inne \\
\hline 10 & 11 & - & 2 & - \\
$\begin{array}{l}\text { Jedna ze studentek dodała: } \\
\text { ALE! } \\
\begin{array}{l}\text { Dużo czasu trzeba na to żeby } \\
\text { takie zajęcie przygotować }\end{array}\end{array}$ & $\begin{array}{l}\text { Jedna ze studentek dodała: } \\
\text { nie chce być nauczycielka, ale } \\
\text { jeśli kiedyś... to TAK }\end{array}$ & & & \\
\hline
\end{tabular}

V. Czy Pani jako studentka chciałaby omawiać słuchowiska radiowe na zajęciach JPJO?

\begin{tabular}{|c|c|c|c|c|}
\hline raczej tak & tak & nie & raczej nie & inne \\
\hline 7 & 14 & - & 2 & - \\
\hline
\end{tabular}

Podsumowując wyniki badań ankietowych, z pewnością można powiedzieć, że taki rodzaj sztuki śmiało można wprowadzać na zajęciach JPJO, eksperymentując jednocześnie z różnego typu ćwiczeniami. Lekcja oparta na materiale słuchowiska radiowego uzyskała bowiem ogromną aprobatę respondentów. Tylko dwie osoby wypowiedziały się negatywnie o zadaniach tego typu: 1) Uważam, $\dot{z}$ e wprowadzenie stuchowiska radiowego nie jest dobrym pomystem, dlatego że

2 Podaję oryginalne odpowiedzi respondentek, bez poprawiania błędów.

3 Jedna osoba nie udzieliła odpowiedzi na to pytanie. 
jest ono wystarczajaco dtugie. Lepiej byłoby właczać krótsze wideo, żeby studenci się nie znudzili; 2) Nie za bardzo spodobało mi się zadanie zwiazane ze stuchowiskiem radiowym, dlatego że stuchowiska zwykle sa za dtugie (około 30-40 minut). Moim zdaniem, w ciagu jednych zajęć warto zmieniać aktywność uczniów, np. jeżeli zajęcia dotycza stuchania można najpierw postuchać piosenkę, potem zobaczyć krótkie wideo, poźniej postuchać jakąs historię. Ale ważne jest, żeby nie byty one (czyli wideo, historia) dtugie (nie więcej 15 minut). W taki sposób uczniowie nie sa zmęczeni wykonaniem tylko jednego zadania, ciagle zmieniaja aktywność. Ale może to tylko ja jestem takim człowiekiem, któremu trudne jest skupienie się na czymś jednym przez długi czas. Druga wypowiedź sugeruje, że studentka nie do końca zrozumiała, kiedy właściwie należy słuchać nagrania: oczywiście że puszczanie całego słuchowiska radiowego na zajęciach jest nierozsądne, zajmuje dużo czasu, najlepiej dawać je do posłuchania na zadanie domowe.

Należy nadmienić, że słuchowiska radiowe są ważną częścią polskiej kultury. Od 2001 roku w Sopocie corocznie odbywa się Festiwal Teatru Polskiego Radia i Teatru Telewizji Polskiej „Dwa Teatry”, na którym oceniane są między innymi słuchowiska radiowe wyemitowane na antenie w ciągu roku poprzedzającego edycję festiwalu. W toruńskim Wydawnictwie Adam Marszałek wydawane są książki z tekstami słuchowisk radiowych: Andrzej Mularczyk Cicho, szeptem i na ucho (2006); Jerzy Górzański Życie do końca życia (2007); Bogdan Loebl Wesotych świat (2007); Piotr Müldner-Nieckowski Piórko. Dramaty radiowe (2007). Ponadto o wadze tej sztuki świadczy również fakt, że 28 maja 2018 roku powstała Fundacja Teatr Wyobraźni. Na stronie internetowej czytamy: „Jednym z głównych celów Fundacji jest wspieranie wszelkiej działalności na rzecz upowszechniania dorobku Teatru Polskiego Radia, teatru i słuchowisk radiowych. Staramy się zachęcić animatorów kultury i nauczycieli do wykorzystywania słuchowisk w edukacji kulturowej" (http://teatrwyobrazni.pl/).

$\mathrm{Na}$ rzecz słuchowiska radiowego jako sztuki przemawiają również liczne życzliwe opinie słuchaczy, umieszczone pod słuchowiskami w serwisie YouTube. Wart uwagi jest komentarz zamieszczony pod słuchowiskiem Czarna pani: „Dziękuję bardzo, jestem z Anglii uczę się polskiego. To jest bardzo fajne. Subscribed :)". Przedstawiony fragment skłania do wniosku, że inni obcokrajowcy uczący się polszczyzny równie chętnie sięgają po omawiany typ nagrań.

\section{Konkluzja}

Słuchowisko jest bogatym źródłem frazeologizmów i wyszukanych zwrotów, choć zdarzają się także elementy stylu potocznego. Czasami występują nawet przekleństwa, wulgaryzmy, na przykład w Dwóch mężczyznach na moście autorstwa Krystyny Kleczkowskiej (emisja: 2009; https://www.youtube.com/ watch?v=ffRIncD9jU4) czy Smaku Marka Zgaińskiego w adaptacji i reżyserii Ro- 
berta Mirzyńskiego (emisja: 2005; https://www.youtube.com/watch?v=CxuPlMchdWg\&t=3s). Oznacza to, że cudzoziemiec ma możliwość posłuchania zarówno polszczyzny wzorcowej, jak i potocznej. Dialogi brzmią bardzo naturalnie, są odegrane przez zawodowych aktorów, od których możemy uczyć się wymowy i polskiej intonacji. Interesująca fabuła trzyma słuchacza w napięciu. W słuchowisku czasami pojawia się kilka wątków, co jest jedną z zalet tej sztuki (zresztą jak prawie każdej innej), pozwalającą na wielość interpretacji, a co za tym idzie różnorodność tematów i kwestii do omówienia na zajęciach z uczniami. Poza tym jest to rodzaj „bajkoterapii dla dorosłych”, rozrywka, sposób na wyciszenie się, recepta na jeszcze jedno życie, stworzone przez naszą wyobraźnię. Jak napisała jedna z moich studentek: stuchowisko radiowe to sztuka. Każdy odbiorca odnajduje w niej swoje własne niepowtarzalne nuty i dźwięki, które powoduja u niego wibracje uczuć.

\section{Bibliografia}

Bauman A., Gość wigilijny, https://www.youtube.com/watch?v=YIRRTDej-tI (dostęp: 19.05.2020).

Bauman A., Złodziej głosów, https://www.youtube.com/watch?v=vtYQ7mmkRNg (dostęp: 19.05. 2020).

Bachura J., Odstony wyobraźni. Wspótczesne stuchowisko radiowe, Toruń 2012.

Bardijewska S., Nagie stowo: rzecz o stuchowisku, Warszawa 2001.

Fundacja Teatr Wyobraźni, http://teatrwyobrazni.pl/ (dostęp: 19.05.2020).

Górzański J., Życie do końca życia, Toruń 2007.

Kleczkowska K., Dwaj mężczyźni na moście, https:/www.youtube.com/watch?v=ffRIncD9jU4 (dostęp: 19.05.2020).

Lem S. (autor), Melina M. (reżyser), Czy pan istnieje, mr Johns?, https://www.youtube.com/watch? $\mathrm{v}=2 \mathrm{kSNx}-\mathrm{Jz} 4 \mathrm{NA} \& \mathrm{t}=463 \mathrm{~s}$ (dostęp: 19.05.2020).

Loebl B., Wesolych świat, Toruń 2007.

Loebl B., Wirus, https://www.youtube.com/watch?v=s7kI48UxcKU (dostęp: 19.05.2020).

Ławrynowicz M., Józio, https://www.youtube.com/watch?v=_IME_h9nLHA\&t=14s) (dostęp: 19.05. 2020).

Mularczyk A., Cicho, szeptem i na ucho, Torun 2006.

Müldner-Nieckowski P., Piórko. Dramaty radiowe, Torun 2007.

Orłoś K., Czarna pani, https://www.youtube.com/watch?v=6aOAMAX95IE\&t=75s (dostęp: 19.05. 2020).

OrłośK.,Spadkobiercy, https://www.youtube.com/watch?v=YSy_EwXYNcM(dostęp: 31.05.2020).

Osowicka-Kondratowicz M., „Bajki samograjki”, czyli o stuchowiskach i ksiazkach do stuchania w rozwoju mowy dziecka, „Prace Językoznawcze” 20, 2018, nr 2, s. 141-156.

Pawlik A., Teatr radiowy i jego gatunki, Toruń 2014.

Pleszkun-Olejniczakowa E., Bachura J., Pawlik A., Dwa Teatry. Studia z zakresu teorii i interpretacji sztuki stuchowiskowej, Toruń 2011.

Trębska-Kerntopf A., Co słychać w stuchowisku, czyli o technikach pracy z teatrem wyobraźni na zajęciach języka polskiego jako obcego, „Acta Univeritatis Lodziensis. Kształcenie Polonistyczne Cudzoziemców" 18, 2008, s. 63-69.

Zgaiński M., Smak, https://www.youtube.com/watch?v=CxuPlMchdWg\&t=3s (dostęp: 19.05.2020).

Kształcenie Językowe 18 (28), 2020

(C) for this edition by CNS 